\title{
A MOVEABLE FEAST: LIFE IN THE CHURCH AS EDUCATION AND CELEBRATION
}

\author{
Dmitry I. Makarov*
}

Abstract: Life in the Church, taken in all the complexity of its interconnections, is a moveable feast. But there exists a misconception of the Church among the young as of something dull. To overcome this situation, we must be open to the young and to correspondingly transform our juvenile policy. By disclosing to the young the plenitude of meanings of the Orthodox Liturgy (through missionary liturgy), of Orthodox poetry and culture, by holding seminarsdiscussions like, e.g., The Meaningful Cinema with the aim of showing some real parallels between the Orthodox faith and the great masters' search for truth in mind, we may be instrumental in turning the young people all over different countries into a part of our sobornost and in their attaining of their own hypostases of ecclesiastical existence (Metropolitan John Zizioulas).

Keywords: Church life, hypostasis of ecclesiastical existence, J. Zizioulas, word, spirit, feast, culture, education, tradition, Christocentrism, logocentrism, Saints as heroes, liturgy, missionary liturgy, juvenile policy of the Church.

The generation gap is one of the most pressing problems we are faced with in the Church now. Throughout the globe the youth avoids visiting the Church and deems it worthy for the venerable age only because of the putatively dull (if not depressing) and incomprehensible character of the ecclesiastical life.

Analogous difficulties mark the way of the contemporary Christian religious philosophy (this is what we see in Russia now). Characteristically enough, Serguey Khoruzhy (2015) laments that Rev. Georges Florovsky's The Ways of Russian Theology (1937) neither can find any congenial adherents today, nor have been duly understood ${ }^{1}$.

${ }^{*}$ Dr. of sciences in philosophy, associate professor, head of the department of general humanities at the Urals State M.P. Mussorgsky Conservatoire, Ekaterinburg, Russia.

${ }^{1}$ Serguey S. Horuzhy, The conception of neopatristic synthesis on a new stage [in Russian], in: „Voprosy filosofii”, vol. 7 (2015): 122 - 135, here 132 - 134. 
This is not to say that contemporary Russian philosophy despite all its diversity does not grasp those subtle meanings of words in literature and in prayer, in myth and in a fairy tale, that served as a source of inspiration for Pushkin (I mean The Prophet and other poems), Lermontov, Gogol, Dostoevsky, Pasternak et al. These globally renowned writers and thinkers were all Orthodox Christians (surely, not always free from dogmatic and ethical problems concerning their faith), and such an intimate attitude towards the word as such, towards the logos ascending one's mind high above, to that Logos that "was God... and became flesh" (Jn. 1, 1. 14), was inherited by the most prominent Russian intellectuals of the present day. So, to adduce but one example, the great philologist and philosopher Vladimir Toporov (1928 - 2005) underlined that "...it is preeminently the word that constitutes that original center in which the development of [human] spirit takes place and where such depths of this spirit are disclosed that had been hitherto unknown"2. We may, and should, infer from this deliberation of V. N. Toporov, as well as from other sources, that our attitude to the word in general, and to the sacred word, to the word in Church worship and ritual, is one of the criterions of our Orthodoxy and of our having or having not reached the age of 'adults' in Christ (cf. Eph. 4, 13). This is what our children and younger generations should be instructed in by all the means available. And do we not possess a brilliant collection of the masterpieces of Orthodox literature accommodated for children and teenagers? I am confident that, except for the multi-volume Romanian translation of the Philokalia by Father Dumitru Staniloae, there should appear shorter excerpts and/or florilegia from these

2 Vladimir N. Toporov, Sign and Text in Space and Time [in Russ., 1993 1995], in: "Slavica Revalensia II" (Tallinn, 2015): 146. Cf. in Heidegger: "Each statue, each temple, each flute playing would be nothing, if they did not 'grow roots' in word..." (Cited in our back translation from the Russian rendering of his Heraclitus: Martin Heidegger, Geraklit. 1. Nachalo zapadnogo myshlenija. 2. Logika. Uchenie Geraklita o Logose, trans. from German by A. P. Shurbelev (St Petersburg, 2011): 111). 
volumes, to be used not only at the faculties of Orthodox theology but also at the parishes and in Sunday schools throughout the country. And where we preserve the Orthodox word and spirit, which are closely interconnected, there we preserve the Orthodox faith itself.

Once again, one cannot pursue this aim of preserving our faith without facing difficulties. While discussing this theme, I will also limit myself to one example only. So, in 2005 the famous poet and philosopher Olga Sedakova delivered a public lecture with the penetrating caption Mediocrity as a Social Danger. In this text she corroborated with new arguments Dmitry Merezhkovsky's thesis about the oncoming Ham and the triumph of mediocrity in the immediate future. This future turned up to be our reality nowadays. As Sedakova witnesses, "The $20^{\text {th }}$-century experience turned out to be an unimaginable shock for the European civilization as a whole" . But our Church possesses a great moral and ontological resilience, so it is able to survive even in dire straits. It will never deviate from its mission, inherited from our Lord Jesus Christ, Who is "the same yesterday, and today, and for ever" (Heb. 13, 8), to be a ship of salvation for the faithful. The great deeds of such contemporary Saints as Saint John of Kronstadt, the Russian New Martyrs, or of the blessed elder Cleopa (Ilie), corroborate our words, leaving no room for doubt.

This is why we know for sure from all our living experience and practical wisdom, that such a perception of the Orthodox Church as of something prehistorical is far from being true. Life in the Church is a moveable feast. To make this clear to the young is our most important missionary task.

3 Olga A. Sedakova, Mediocrity as a Social Danger [in Russian], in: “Muzykal'noe obozrenie", no. 12 (393) (2015): 21 - 26, here 25. 
More than that, culture in its essence (be this a 'hierarchy of reverences' [Vyacheslav Ivanov ${ }^{4}$ ] or something else) is always an overcoming and a transcending of the world of dullness. It is basically a liberation from a person's or a people's submission to mediocrity, to advertisement, to clip thinking and so many other denominators of our mundane being here and now. I would not now dwell upon a vexed question of genius and malignity, but let me turn to such a pressing problem for us all as that of the formation of Orthodox ecclesiastical culture among our younger generations.

But how should we do this? How to instill this love for and veneration of Orthodoxy to the young people's minds and hearts? One of the most important answers, which might have been historically the most important one, is well-known from the outset. As Sergei Averintsev stressed (together with many other experts in the field, like, e.g., His Eminence Kallistos (Ware) of Diokleia), "...for the Orthodox liturgical sense, worship as a whole, not exclusively at the moment of Transubstantiation, is a mystery of the transcendent Presence" 5 . And we know, following the Byzantines and the peoples of the 'Byzantine Commonwealth', that: "Now the Celestial Powers are present with us, and worship invisibly" 6 . In order to make liturgy, Vespers and the other services comprehensible to the younger part of their flock, many priests in contemporary Russia (to adduce but one example) practice the so-called missionary liturgy, when each member of the community receives before the celebration a booklet with the Church Slavonic text, accompanied by its Russian translation and an explanation of the difficult expressions,

${ }^{4}$ See Vyacheslav Ivanov, Mikhail Gershenzon, The Correspondence from the Two Angles [1920]. Vyacheslav Ivanov's Third letter to Gershenzon from June 19, 1920 // https://books.google.ru/books?isbn=5447506980.

5 Serguey S. Averintsev, Some constant characteristics of Byzantine Orthodoxy, in: Andrew Louth and Augustine Casiday (eds.), Byzantine Orthodoxies. Papers from the Thirty-sixth Spring Symposium of Byzantine Studies, University of Durham, 23-25 March 2002 (Bodmin, Cornwall: Ashgate, 2006): 215-228, here 219.

${ }^{6}$ Cf. ibid. 
together with an Orthodox exegesis of the general meaning of a certain worship. I deem it to be an effective way of explaining in greater detail the significance and the meanings of the Church services both to serious believers (even they may somehow need it) and to Sunday-goers. The process of a person's (or a community's) upbringing in an Orthodox understanding is, as we know, exactly a combination of education with the ethical formation of his or her. This formation may take place in an implicit manner, as, e.g., by watching the Orthodox (or compatible with Orthodoxy) movies; even football cups of a bishop or of a Metropolitan may be held on certain dates, etc. Our Ekaterinburg chair of theology held the special seminar The Meaningful Cinema each Thursday for more than a decade, thus bringing together Orthodox youth even from other institutions and making the young people communicate with each other. Of course, we mostly saw Russian movies, like those based on Dostoevsky's novels, but in Romania or any other country people may make their own choice and to watch, say, the masterpieces of Fellini, Bergman or Almodóvar. It depends. The main condition is such that the movies in question should teach young hearts to do good and justice to other people and to themselves, even against evil. As the Apostle advised: Recompense to no man evil for evil. Provide things honest in the sight of all men (Rom. 12, $17 \mathrm{KJV}$ ).

We must not forget, at least, one extremely important feature of the young people's consciousness and world outlook, regardless of the century in which they lived or will live. The youth in every country on earth strives for feat, for heroic deeds, in their desire (be this conscious or not, it is another question) to emulate their forefathers. We speak a lot of words nowadays against any attempts at rewriting history, not in the last turn that of the World War II. But the history of the Christian Church is full of heroic deeds. There is a widely circulating idea that a Christian Saint is exactly what a hero in a profane consciousness is meant to be. No wonder: all ancient Christian martyr stories go back to the Jewish national heroes, who 
were the Maccabees ${ }^{7}$. Anyway, we may and must have our missionary profit on this dictum. For each epoch calls for heroes. And the Christian ones, whom we may offer to the world, are for all time.

In a word, we must enlarge and deepen our juvenile policy by making it not a policy (implying a kind of a mutual alienation of the 'adults' and the 'kids'), but a way of mutual coexistence through our common acquiring of each believer's hypostasis of ecclesiastical existence, i.e., through the practice of virtue, Eucharist and prayer (Metropolitan John Zizioulas ${ }^{8}$ et al.). In the final analysis, this is what determines the ecclesiastical life in its unity and diversity at the same time. Theologically speaking, a human person from such an Orthodox viewpoint is not a separate individual, but a part of sobornost, or, in other words, of a unity-in-diversity of all the believers, belonging to the Orthodox Church in its integrity. To quote a contemporary expert: "In the final analysis, realization of the Trinitarian principle of the unity in diversity in what a person's interrelationship with the Divine Persons and other human beings is concerned means this person's attainment of the Christian love in its plenitude" . This love is the main factor determining a Christian's life as well.

${ }^{7}$ See, e.g., Michel van Esbroeck, "The Saint as a Symbol”, in: Serguey Hackel (ed.), The Byzantine Saint (Crestwood, NY, 2001): 128-140, here 128; 134: the fourth book of Maccabees is "...the model for all Christian passion narratives". ${ }^{8}$ See John D. Zizioulas, Being as Communion. Studies in Personhood and the Church (N.Y., 1993). Ch. 1, pt. 2. We used the Russian translation of the book: Ioann (Zizioulas), metr., Bytie kak obschchenie. Ocherki o lichnosti i Cerkvi, trans. by D. M. Gzgzyan (Moscow, 2006): 46, 49 sq.

${ }^{9}$ Serguey A. Chursanov, "The Trinitarian principle of the unity in diversity in the theology of the Great Cappadocians and in the Orthodox anthropology of the $20^{\text {th }}$ and $21^{\text {st }}$ centuries" [in Russian: "Trocihnyj princip edinstva $v$ razlichii $v$ bogoslovii Velikikh Kappadokijcev i pravoslavnoj anthropologii XX - XXI vekov"], in: Dukhovnoe nasledie Vizantii i Afona $v$ istorii $i$ kul'ture Rossii. Materialy konferencij (2007 - 2015 gg.) (Moscow, 2016): 105 - 114, here 109. 
This life always bore features of the feast. If we look at the history of the Roman Church in Spain in the $16^{\text {th }}$ and $17^{\text {th }}$ centuries, we'll see that feasts and those religious fraternities which organized them featured prominently in the life of town and village ${ }^{10}$.

But should not the Orthodox processions with the Cross (and other feasts) play the same role in the Orthodox world? The diversity of forms in which the Church and secular culture interact with each other can be considerably increased. We've got to turn the young people into a part of our sobornost so that they may have felt our permanent festive spirit and thereupon may acquire Christ in their lives.

And this is also the way of our defending the principles of creative development, of Christocentrism and logocentrism, priority of the Logos of God over absurd of life and any mundane, secular affairs, i.e., the principles which are basic for any culture with Christian self-determination.

As a result of all the aforesaid, I do believe that, this being so, such a good life would instill new and blissful thoughts into the young, and our societies will have good reasons to expect that in a decade or two new pastors may appear who would be ready to give up their souls for their flock. I also hope that among them we will see new eminent historians and theologians who would be the spiritual heirs of such genii as Fr. Staniloae and Fr. Florovsky.

10 See Denis G. Fedosov, "Religioznye bratstva i prazdnichnaya kul'tura Ispanii i Latinskoy Ameriki XVI - XVII vekov", in: I. V. Kondakov (ed.), Estetiko-kul'turologicheskie smysly prazdnika. Sbornik statey pamyati A.I. Mazayeva (Moscow, 2009): 327-343, here 327-336. 